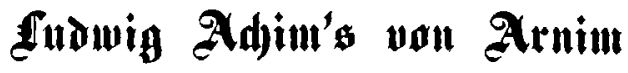

\section{fämutlidbe merke.}

Eedfebnter $3 a n b$.

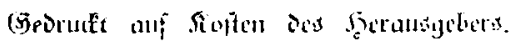

\section{erliir, 1846.}

Ẹpedition bes v. 21rnimfifen Jerhgs. 

(f) alle und 3erufaleur.

Stubentenipiel uns soilgernbentener

von

fubwig 2 Adiun won Axnim.

riseruft auf Stoften ses Setausigebers.

Derliir, 1846.

Expedition Des v. Urnimfden Werlags. 
